\title{
Phylogenetic Relationships Among the "True Citrus Fruit Trees" by Glutamate Oxaloacetate Transaminase Isozymes Analysis
}

\author{
Mohammad Mizanur Rahman and Nobumasa Nito \\ Facully of Agriculture, Saga University, Honjo, Saga 840
}

\begin{abstract}
Summary
Leaf isozymes of glutamate oxaloaceate transaminase (EC 2.6.1.1; GOT) in the "true citrus fruit trees" group of Citrinae were analyzed using polyacrylamide gel electrophoresis to elucidate phylogenetic relationships among them. Segregation at each of three loci, Got-1, Got-2 and Got-3 of GOT isozymes in the progenies obtained from intergeneric crosses between Citrus and Microcitrus species followed a simple Mendelian inheritance, suggesting that Microcitrus and Citrus species have similar genetic systems and the species of these two genera are closely related to each other. Some common alleles at the three loci controlling GOT isozymes were recognized between the genera of "true citrus fruit trees". These findings suggest that a genetic identity is conserved among the "true citrus fruit trees" group; even some of them climatically, geographically and reproductively isolated.
\end{abstract}

\section{Introduction}

The "true citrus fruit trees" group of the subtribe Citrinae (Rutaceae) is comprised of six genera. Among them, Fortunella, Poncirus, and Cit. rus are native to southeast Asia, Microcitrus and Eremocitrus to Australia, and Clymenia to New Ireland (New Guinea) (Swingle and Reece, 1967).

Cross compatibility has been reported among the members of "true citrus fruit trees" (Barrett, 1977, 1981, 1985; Iwamasa et al., 1988), thus indicating their close relationships. Graft compatibility was also reported among them (Bitters et al. 1977; Sykes, 1988). To date, all phylogenetic studies which have been carried out are mostly concentrated on Citrus (Potvin et al., 1983; Niedz et al., 1991; Gogorcena and Orit2, 1993), but comprehensive phylogenetic relationships among the "true citrus fruit trees" at the genetic level have not yet been clarified.

The present investigation was aimed at elucidating the phylogenetic relationships among the genera of "true citrus fruit trees" by isozyme analysis.

Received for publication 27 July 1993.

\section{Materials and Methods}

\section{Plant materials}

Parent trees and their adult progeny (about 5 years old), which had been obtained from the previous work (Iwamasa et al., 1988), were used to assess genetic determinism (Table 1). All plant materials were maintained in a greenhouse under natural light. The genotypes of Fortunella, Eremocitrus, Microcitrus, and Citrus were identified on the basis of progeny segregation (Rahman and Nito, 1994a).

\section{Protein extraction}

The leaves were selected for protein extraction from the previous spring cycle of growth (approximately 6 months old). Fresh leaf tissue $(0.2 \mathrm{~g})$ was homogenized with $0.5 \mathrm{ml}$ of $100 \mathrm{mM} \mathrm{K}$-acetate buffer, pH 5.4 (Esen and Soost, 1976). The crude homogenate was centrifuged at $14,000 \times \mathrm{g}$ for $20 \mathrm{~min}$. The resulting supernatant was desalted with Sephadex G-25 (Hirai et al., 1986b). All operations were carried out at $4{ }^{\circ} \mathrm{C}$.

\section{Electrophoresis}

Vertical polyacrylamide slab gel electrophoresis (PAGE) was conducted at $4{ }^{\circ} \mathrm{C}$. The separations 
were performed on $2.5 \%$ stacking gel and $7 \%$ separation gel consisting of $1.49 \mathrm{M}$ Tris- $\mathrm{HCl}, \mathrm{pH}$ 8.9. The electrode buffer contained $0.04 \mathrm{M}$ Tris and $0.38 \mathrm{M}$ glycine, $\mathrm{pH}$ 8.3. Protein content was estimated by Lowry's procedure (Lowry et al., 1951) and $50 \mu \mathrm{g}$ protein equivalent of each sample was loaded. The electrophoresis was carried out at a constant current of $12 \mathrm{~mA}$ per gel until the bromophenol blue dye began to run off the gel.

Staining of gels

At the end of electrophoresis, gels were stained for glutamate oxaloacetate transaminase (EC 2.6.1.1; GOT) in the dark at $30{ }^{\circ} \mathrm{C}$ unitl a clear blue band appeared (Torres et al., 1978a). GOT is synonymous with aspartate aminotransferase (AAT). Stained gels were washed and fixed in $7 \%$ acetic acid.

\section{Genetic interpretation}

The principles followed for interpretation of banding patterns and for designation of gene loci and alleles were the same as outlined by Hirai et al. (1986a) and Hirai and Kajiura (1987).

The genetic control of isozyme variants was determined by chi-square analysis of progeny for goodness-of-fit to expected ratios in available crosses.

For making comparisons among the "true citrus fruit trees", the reported alleles of GOT isozymes of Fortunella, Eremocitrus, Poncinus, Microcitrus, and Citrus (Torres et al., 1978b; Hirai et al., 1986a; Hirai and Kajiura, 1987) and Clymenia (Soost and Torres, 1981) were adopted from the previous works.

\section{Results}

Three zones of activity, GOT-1, GOT-2, and GOT-3 (sharing the same zone with GOT-2) were detected on gels stained for GOT. The mobilities of GOT-2 homodimers overlapped those of the GOT-3, making interpretation of some phenotypes difficult. However, it was successfully resolved, based on the progeny segregation patterns. A sample of the different banding patterns observed in this isozymes is shown in Fig. 1.

Crosses between parents with three bands and single-banded GOT-1 phenotypes gave two classes of progenies with sinle-band and three-bands and were produced in approximately equal frequency (Table 1 ). The results can be explained on the basis of progeny segregation for a single gene, (Got-1). The presence of the 'hybrid' band denotes the dimeric structure of this enzyme.

In the GOT-2 zone, progenies obtained from 2 crosses (cross no. 1 and 3 ) among the 4 intergeneric crosses were segregated. In the cross no. 2 and 4 no segregations were obtained because a common homozygous allele is present in both parents (Table 1). The results of segregation at GOT-2 zone are in agreement with the hypothesis that enzymes observed in this zone are coded by a

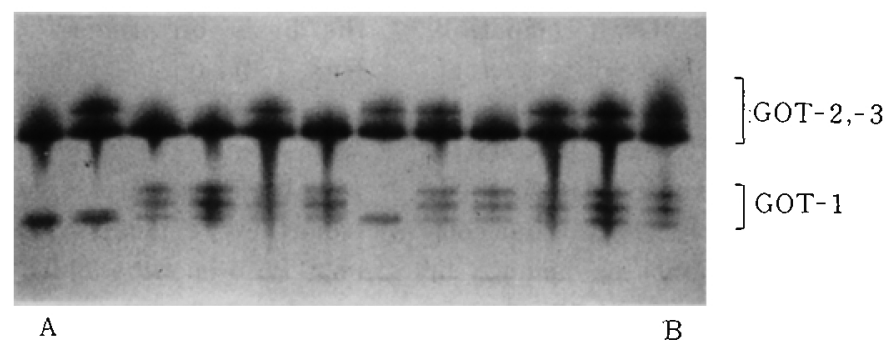

GOT-3 $M_{n} \quad E_{n}\left(M_{n}+t_{n}\right)(M n+n n)$ En $(M n+m n)$ Eịn EM (Mntnn) En En En GOT-2 MM MM MM MM MM MM MM MM MM MM M MM GOT-1 SS SS FS FS FS FS SS FS FS FS FS FS

Fig. 1. Glutamate oxaloacetate transaminase zymograms of progeny from C. iyo (cv. Miyauchi Iyo) (B) $\times M$. inodora (A). Segregation was observed for GOT-1 (FS $\times \mathrm{SS})$ and GOT-3 $(\mathrm{En} \times \mathrm{Mn})$. The origin of migration is at the bottom of the photograph and the band migration is towards the anode. Genotypes within brackets are not distinguishable. 
Table 1. Goodness-of-fit to tests for single locus segregation of genotypes in progenies of controlled crosses between Citnis and Microcitnes.

\begin{tabular}{|c|c|c|c|c|c|c|}
\hline Locus & Cross $^{2}$ & $\begin{array}{l}\text { Parental } \\
\text { genotypes }\end{array}$ & $\begin{array}{l}\text { Progeny no. and } \\
\text { their genotypes }\end{array}$ & $\begin{array}{l}\text { Expected } \\
\text { ratio }\end{array}$ & $\begin{array}{l}\mathrm{Chi}^{-x} \\
\text { square }\end{array}$ & $P$ \\
\hline \multirow[t]{4}{*}{ Got -1} & 1 & $F S \times S S$ & $8 \mathrm{FS}: 4 \mathrm{SS}$ & $1: 1$ & 1.34 & $0.10-0.25$ \\
\hline & 2 & $\mathrm{FS} \times \mathrm{SS}$ & $41 \mathrm{FS}: 38 \mathrm{SS}$ & $1: 1$ & 0.12 & $0.90-0.95$ \\
\hline & 3 & $M M \times M S$ & $14 \mathrm{MM}: 4 \mathrm{MS}$ & $1: 1$ & 5.56 & $0.01-0.05$ \\
\hline & 4 & $\mathrm{FS} \times \mathrm{SS}$ & $25 \mathrm{FS}: 20 \mathrm{SS}$ & $1: 1$ & 0.56 & $0.25-0.50$ \\
\hline \multirow[t]{4}{*}{ Got -2} & 1 & $\mathrm{MM} \times \mathrm{MR}$ & $7 \mathrm{MM}: 5 \mathrm{MR}$ & $1: 1$ & 0.34 & $0.50-0.75$ \\
\hline & 2 & $\mathrm{MM} \times \mathrm{MM}$ & $79 \mathrm{MM}(100 \%)$ & - & - & - \\
\hline & 3 & $\mathrm{MM} \times \mathrm{MR}$ & $12 \mathrm{MM}: 6 \mathrm{MR}$ & $1: 1$ & 2.00 & $0.10-0.25$ \\
\hline & 4 & $M M \times M M$ & $45 \mathrm{MM}: \quad(100 \%)$ & - & - & - \\
\hline \multirow[t]{4}{*}{ Got -3} & 1 & $\mathrm{Mn} \times \mathrm{AM}$ & $4 \mathrm{An}: 4 \mathrm{AM}: 4(\mathrm{MM}+\mathrm{Mn})^{y}$ & $1: 2: 1$ & 2.00 & $0.25-0.50$ \\
\hline & 2 & $M n \times M n$ & $79(M n+M M+n n)$ & - & - & - \\
\hline & 3 & $A M \times A A$ & $14 \mathrm{AM}: 4 \mathrm{AA}$ & $1: 1$ & 5.56 & $0.01-0.05$ \\
\hline & 4 & $E_{n} \times M n$ & $16 \mathrm{En}: 25(\mathrm{Mn}+\mathrm{nn}): 4 \mathrm{EM}$ & $1: 2: 1$ & 6.95 & $0.01-0.05$ \\
\hline
\end{tabular}

2 Cross designation : $1=$ C. grandis (cv. Tosa buntan) $\times$ Sydney hybrid $.2=C$. grandis (cv. Tosa buntan) $\times M$. inodora. $3=$ C. macroptera $\times$ M. australasica. $4=\mathrm{C}$. iyo (cv. Miyouchi lyo) $\times$ M. inodora.

" Genotypes within brackets are not distinguishable.

* Degrees of freedom were. 1 and 2 for $1: 1$ and $1: 2: 1$ ratios respectively.

Table 2. Comparison of common alleles among the genera of "true citrus fruit trees."

\begin{tabular}{|c|c|c|c|c|c|c|c|}
\hline Locus & Allele ${ }^{z}$ & Microcitnis & Citnus & Fortunella & Poncinus & Eremocitns & Clymenia \\
\hline \multirow{7}{*}{ Got -1} & $P$ & - & - & + & + & - & - \\
\hline & $\mathrm{F}$ & + & + & - & - & - & - \\
\hline & $M$ & + & + & + & + & + & - \\
\hline & $W^{y}$ & + & - & - & - & - & - \\
\hline & A. & - & + & - & - & - & - \\
\hline & $S$ & + & + & + & - & + & + \\
\hline & $E^{y}$ & \multirow{2}{*}{-} & - & - & - & + & - \\
\hline \multirow{9}{*}{ Got -2} & A & & + & - & - & - & - \\
\hline & $\mathrm{M}$ & + & + & + & + & + & - \\
\hline & $\mathrm{B}$ & - & + & - & - & - & - \\
\hline & $S$ & - & + & - & + & + & - \\
\hline & $\mathrm{R}^{*}$ & + & - & - & - & - & - \\
\hline & $w^{y}$ & + & - & - & - & - & - \\
\hline & $G^{*}$ & + & - & - & - & - & - \\
\hline & $C^{*}$ & - & - & - & - & - & + \\
\hline & $n^{y}$ & + & - & - & - & - & - \\
\hline \multirow{7}{*}{ Got -3 } & A & + & + & - & - & - & - \\
\hline & C & - & + & - & - & - & - \\
\hline & $\mathrm{E}$ & - & + & + & - & - & - \\
\hline & $\mathrm{D}$ & - & + & - & - & - & - \\
\hline & $\mathrm{B}$ & - & - & + & - & - & - \\
\hline & $M^{y}$ & + & - & - & - & $?$ & - \\
\hline & п & + & + & - & + & $?$ & - \\
\hline
\end{tabular}

+ : Present. - : Absent, ? : Genotype not determined.

Data adopted from Hirai et al. (1986 a) and Hirai and Kajiura (1987). Allele 'A' at Got-2 correspond to ' $F$ ' allele of Torres et al. (1978 b) and Soost and Torres (1981).

* Alleles were newly discovered by the present authors (Rahman and Nito. 1994 a. b).

x Data adopted from Torres et al. (1978 b) and Soost and Torres (1981). 
single gene (Got-2) (Table 1). The presence of an intermediate intensively staining band in the heterozygotes indicates that the enzymes in GOT-2 eynzyme are dimeric.

The segregation of GOT-3 zone from 4 intergeneric crosses (Table 1) suggests that a gene, Got-3, codes for the enzymes in that zone. The results from intergeneric crosses (cross no. 1,2, and 4) suggest that a null allele ' $n$ ' is present in one or both of the parents (Table 1).

Goodness-of-fit tests for single locus segregation of GOT isozymes suggested that each of three loci controlling GOT isozymes in Citrus and Microcitrus have similar genetic systems (Table 1 ).

Alleles recognised at three GOT loci in "true citrus fruit trees" are presented in Table 2. A total of 23 alleles of which 7 at Got-1, 9 at Got-2 and 7 at Got- 3 have been identified. Common ' $M$ ' alleles were observed in Fortunella, Eremocitrus, Poncirus, Microcitrus, and Citrus at Got-1 and Got-2; whereas ' $\mathrm{S}$ ' allele at Got-1 was common to Fortunella, Eremocitrus, Clymenia, Microcitrus, and Citnus (Table 2).

\section{Discussion}

The disjunctive distribution of the "true citrus fruit trees" group is considered to be the result of geological and climatic events. It is assumed that Microcitrus and Eremocitnus migrated into Australia from Asia via New Guinea during the mid-Miocene about 15 MYBP (Raven and Axelrod, 1974; Scora, 1988). According to continental drift hypothesis, Australia and New Guinea were attached to southern Asia before the separation took place during the late Oligocene and Miocene (Benson, 1923; Brough, 1933; Scora, 1988). It is predicted that before separation all the "true citrus fruit trees" had distributed sequentially in Asia and originated from the same ancestor (Scora, 1988; Iwamasa and Nito, 1988).

Some common isozyme bands of amylase and peroxidase were observed among "true citrus fruit trees" to indicate their close relationships (Esen and Soost, 1976; Esen and Scora, 1977). Handa et al., (1986) on the basis of Fraction I protein analysis suggested that Fortunella, Poncirus, and Citrus are closely related to one another. The same results were obtained in numerical taxonomic studies based on morphological characters (Barrett and Rhodes, 1976; Handa and Oogaki,
1985).

The chromosomal numbers of the six genera of "true citrus fruit trees" reported to be identical ( $2 \mathrm{n}$ =18) (Krug, 1943; Marcelo and Guerra, 1984. 1985). On the basis of chromosome pairing in meiosis in the intergeneric hybrids, it was concluded that the four genera (Fortunella, Poncinus, Microcitrus, and Citrus) of "true citrus fruit trees" represent the same genome (Nakamura, 1934, 1942; Naithani and Raghuvanshi, 1962; Iwamasa and Nito, 1988).

In this study, some common alleles between "true citrus fruit trees" at the three loci controlling GOT isozymes were recognized (Table 2), confirming the close affinity among the genera. As both our finding and all the above mentioned literatures show evidence of close affinity relationships among "true citrus fruit trees", it would be conceivable to consider that six genera of the "true citrus fruit trees" originated from the same ancestor as reported previously (Scora, 1988; Iwamasa and Nito, 1988).

Cross compatibility has been reported between some members of "true citrus fruit trees", and no isolating barrier of intersterility was observed between Citnus and Microcitrus species (Barrett, 1977, 1981, 1985; Iwamasa et al., 1988). Somatic hybridizations were also reported between the genera of "true citrus fruit trees" (Ohgawara et al. 1985; Vardi et al., 1989; Deng et al., 1992). Though the species of these two genera have been isolated from each other for tens of million of years, genetic identity between the two genera has been clarified to be conserved. Isozyme analysis in this study indicated that Citrus and Microcitrus had similar genetic systems. These findings support that a close affinity exists between the genome of Citrus and Microcitrus. This genome affinity of the species in the two genera is supported by the cytogenetic evidence from an in tergeneric hybrid (Iwamasa and Nito, 1988).

The genus Clymenia has no sexual compatibility with Citrus; whereas the other four genera of "true citrus fruit trees" have the compatibility (Sykes, 1988). The Clymenia is considered to be a somewhat distant relative of the other five genera of "true citrus fruit trees" (Swingle and Reece, 1967). In this isozyme study, alleles ' $M$ ' at Got-1 and ' $\mathrm{M}$ ' at Got.2 were commonly observed in Fortunella, Eremocitrus, Poncirus, Microcitrus, and 
Citrus, but they were not found in Clymenia (Table 2), suggesting divergence of Clymenia from the other five genera of "true citrus fruit trees".

The ' $\mathrm{S}$ ' allele at Got-1 is commonly observed in the five genera of "true citrus fruit trees" including Clymenia. The existence of this common allele suggests that the Clymenia still conserves a genetic identity with Fortunella, Eremocitrus, Microcitrus, and Citrus; although, now Clymenia has been highly differentiated from the other "true citrus fruit trees".

In this research, we recognized some common alleles at three loci of GOT isozymes between the six genera of "true citrus fruit trees", suggesting that a certain degree of genetic identity is maintained among the genera.

The electrophoretic results of this study support the previous phylogenetic assessment (Barrett and Rhodes, 1976; Handa and Oogaki, 1985; Handa et al., 1986; Iwamasa and Nito, 1988) regarding "true citrus fruit trees" that all six genera viz. Fortunella, Eremocitrus, Poncirus, Clymenia, Microcitrus and Citrus represent the same genome and originated from the same ancestor. The data were consistent with the cytogenetic evidence in this regard. This discovery contributes to understanding the evolution of species in subtribe Citrinae (Rutaceae).

\section{Acknowledgments}

The authors are grateful to Dr. S. Isshiki of Saga University, for critical reading of the manuscript and for making valuable suggestions.

\section{Literature cited}

Barrett, H. C. 1977. Intergeneric hybridization of Citrus and other genera in citrus cultivar improvement. Proc. Int. Soc. Citriculture 2 : 586-589.

Barrett, H. C. 1981. Breeding cold hardy citrus scion cultivars. Proc. Int. Soc. Citriculture 1 : 61-66.

Barrett, H. C. 1985. Hybridization of Citrus and related genera. Fruit Var. J. 39: 11-16.

Barrett, H. C. and A. M. Rhodes. 1976. A numerical taxonomic study of affinity relationships in cultivated Citrus and its close relatives. Syst. Bot. 1 : 105-136.

Benson, W. N. 1923. Paleozoic and mesozoic seas in Australia. Trans. New. Zeal. Inst. $54: 1-62$.

Bitters, W. P., D. A. Cole and C. D. McCarty. 1977. Citrus relatives are not irrelevant as dwarfing stocks or interstocks for Citrus. Proc. Int. Soc. Citriculture $2: 561-567$.
Brough, P. 1933. The life history of Grevillea robusta (Cunn.) Linn. Soc. N. S. Wales Proc. $58: 33-73$.

Deng, X. X., J. W. Grosser and F. G. Gmitter Jr. 1992. Intergeneric somatic hybrid plants from protoplast fusion of Fortunella crassifolia cultivar 'Meiwa' with Citrus sinensis cultivar 'Valencia'. Scientia Hortic. $49: 55-62$.

Esen, A. and R. K. Soost. 1976. Peroxidase polymorphism in Citrus. J. Hered. $67: 199-203$.

Esen, A. and R. W. Scora. 1977. Amylase polymorphism in Citrus and some related genera. Amer. J. Bot. 64 : 305-309.

Gogorcena, Y. and J. M. Oritz. 1993. Use of multivariate analysis in the taxonomy of Citrus aurantium L. and relatives. Scientia Hortic. $53: 301-310$.

Handa, T. and C. Oogaki. 1985. Numerical taxonomic study of Cilrus and Fortunella using morphological characters. J. Japan. Soc. Hort. Sci. 54 : 145-154.

Handa, T., Y. Ishizawa and C. Oogaki. 1986. Phylogenetic study of Fraction I protein in the genus Citrus and its close related genera. Japan. J. Genet. $61: 15-24$.

Hirai, M. and I. Kajiura. 1987. Genetic analysis of leaf isozymes in Citms. Japan. J. Breed. $37: 377-388$.

Hirai, M., I. Kozaki and I. Kajiura. 1986a. Isozyme analysis and phylogenetic relationship of Citrus. Japan. J. Breed. $36: 377-389$.

Hirai, M., I. Kozaki and I. Kajiura. 1986b. The rate of spontaneous inbreeding of trifoliate orange and some characteristics of inbred seedling. Japan. J. Breed. $36: 138-146$.

Iwamasa, M. and N. Nito. 1988. Cytogenetics and the evolution of modern cultivated citrus. Proc. Sixth Int. Citrus Cong. 1 : 265-275.

Iwamasa, M., N. Nito and J. Ling. 1988. Intra- and intergeneric hybridization in the orange sub-family, Aurantioideae. Proc. Sixth Int. Citrus Cong. 1 : 123-130.

Krug, C. A. 1943. Chromosome numbers in the subfamily Aurantioideae with sepcial reference to the genus Citris. Bot. Gaz. 104 : 602-611.

Lowry, O. H., N. J. Rosebrough, A. L. Farr and R. J. Randall. 1951. Protein measurement with the Folin-phenol reagent. J. Biol. Chem. 193 : 265-275.

Marcelo, D. and S. Guerra. 1984. New chromosome numbers in Rutaceae. Pl. Syst. Evol. 146: 13-30.

Marcelo, D. and S. Guerra. 1985. Cytogenetics of Rutaceae. III. Heterochromatin patterns. Caryologia $38: 335-346$.

Naithani, S. P. and S. S. Raghuvanshi. 1962. Studies in meiotic behavior of Rusk- an intergeneric hybrid between Citrus and Poncinus. Proc. Natl. Acad. Sci. India, Section B $32: 185^{-188 .}$

Nakamura, M. 1934. Cytological studies in the genus Citrus II. The chromosome number, pollen sterility 
and the formation of abnormal pollen tetrads. (in Japanese with English summary). Studia Citrologia 6:162-178.

Nakamura, M. 1942. Cytological studies in the genus Citrus III. Further data on the chromosome numbers. (in Japanese with English summary). J. Hort. Assoc. Japan 13:30-41.

Niedz, R. P., M. G. Bausher and C. J. Hearn. 1991. Detection of Citnus leaf and seed glycoproteins using biotinylated lectin probes. HortScience 26 : 910-913.

Ohgawara, T., S. Kobayashi, E. Ohgawara, H. Uchimiya and S. Ishii. 1985. Somatic hybrid plants obtained by protoplast fusion between Citnis sinensis and Poncinus trifoliata. Theor. Appl. Genet. $71: 1-4$.

Potvin, C., Y. Bergeron and J. P. Simon. 1983. A numerical taxonomic study of selected Citrus species (Rutaceae) based on biochemical characters. Syst. Bot. $8: 127-133$.

Rahman, M. M. and N. Nito. 1994a. Inheritance and linkage relationships of glutamate oxaloacetate transaminase isozymes in Microcitmus. J. Japan. Soc. Hort. Sci. $62: 749-754$.

Rahman, M. M. and N. Nito. 1994b. Use of GOT isozymes for detection of hybrids among genera of the "true citrus fruit trees." Scientia Hortic. (In press).

Raven, P. H. and D. J. Axelrod. 1974. Angiosperm biogeography and past continental movements.
Ann. Miss. Bot. Gard. 61: 539-673.

Scora, R. W. 1988. Biochemistry, taxonomy and evolution of modern cultivated citrus. Proc. Sixth Int. Citrus Cong. $1: 277-289$.

Soost, R. K. and A. M. Torres. 1981. Leaf isozymes as genetic markers in citrus. Proc. Int. Citriculture 1 $: 7-10$.

Swingle, W. T. and P. C. Reece. 1967. The botany of citrus and its wild relatives. p. 190-400. In: W. Reuther, H. J. Webber and L. D. Batchelor (eds.). The Citrus Industry Vol. 1, Univ. Calif. Press, Berkeley, Calif., U.S.A.

Sykes, S. R. 1988. Overview of the family Rutaceae, p. 93-100. In: R. R. Walker (ed.). Citrus breeding workshop. CSIRO, Melbourne, Australia.

Torres, A. M., U. Diedenhoffen, B. O. Bergh and R. J. Knight. 1978a. Enzyme polymorphisms as genetic markers in the avocado. Amer. J. Bot. 65 : 134-139.

Torres, A. M., R. K. Soost and U. Diedenhoffen. 1978b. Leaf isozyme as genetic markers in Citrus. Amer. J. Bot. $65: 869-881$.

Vardi, A., P. Arzee-Gonen, A. Frydman-Shani, S. Bleichman and E. Galun. 1989. Protoplast-fusionmediated transfer of organelles from Microcitrus into Citrus and regeneration of novel alloplasmic trees. Theor. Appl. Genet. $78: 741-747$.

\title{
グルタミン酸オキザロ酢酸アミノ基転移酵素（GOT）アイソザイム分析による 真正カンキツ類の系統分化の解明
}

\author{
Mohammad Mizanur Rahman・仁藤伸昌
}

佐賀大学宸学部 840 佐賀市本庄町

\begin{abstract}
摘 要
カンキツ亜連，真正カンキツ類の系統分化㧍よび類 縁関係を検討するため，葉のグルタミン酸オキザロ酢 酸アミノ基転移蟀素（EC 2.6.1.1; GOT） アイソザ イムについてポリアクリルアミドゲル電気泳動法を用 いて分析を行った。

カンキツ属とミクロシトラス属の属間交雑実生のア イソザイム分析の結果，GOTを支配するGot-1，Got-2 およびGot-3の3 遺伝子座にお忛る遗伝子型の分雒が

それぞれ単純なメンデル遺伝に従うことを確認した。 このことから，これら２属が類似の遗伝系を持ち，近 縁であることが推察できた．

真正カンキツ類 6 属の Got-1 Got-2 およびGot-3 に おいて互いに共通するいくつかの対立遺伝子が認めら れた，真正カンキツ類 6 属は地理的分布や交雑親和性 などで隔嚁されているが，古る程度の遺伝子的相似度 を互いに維持していることが示嘫された．
\end{abstract}

